\title{
Evaluation of Transaction Cost of Peasant Economy in Southern Thailand
}

\author{
Chinasak Suwan-achariya (Corresponding author) \\ Faculty of Economics and Business Administration, Thaksin University \\ 140 Karnchanavanich Road, Muang Songkhla 90000, Thailand \\ Tel: 66-8-6857-7501Ｅ-mail: chinasak2000@yahoo.com \\ Piyapong Chanpaso \\ Faculty of Economics and Business Administration, Thaksin University \\ 140 Karnchanavanich Road, Muang Songkhla 90000, Thailand \\ Tel: 66-8-493-003-543 E-mail: piyapong_tm@hotmail.com
}

Received: January 26, 2011 Accepted: March 7, 2011 doi:10.5539/ijbm.v6n8p122

\begin{abstract}
This research aims to study the measure of transaction cost indicators and to evaluate the transaction cost of peasant economy. The study found that government's operating system and policy-making was the mainspring of peasants' difficult being since it made those famers face with high level of the transaction cost and subsequently leaded to lowered peasant economy's last revenue unit. Those problems finally leaded to permanent transaction cost which significantly impacted peasants' lack of liquidity in capital reproduction.

The result showed that collaboration as long-term partners is an essential to generate lowered transaction cost of peasant economy and provided the environmental condition appropriate to peasant economy conducive to enhance their well-being in the future.
\end{abstract}

Keywords: Value evaluation, Transaction cost, Commercial rice farming, Peasant economy, Market

\section{Introduction}

Nowadays, most peasants in Thailand are faced with production problems and poverty. Although the government attempts to assist agriculturalist by using price mechanism measure for example intervention of rice price, Purchase of surplus production, pawn or even the present measure implemented by the government i.e. Measures to guarantee income to peasants. Nevertheless, this adjustment of measure cannot provide the resolution to farmer's problems. It is mainly because the problem-solving is not operated to the root causes of problems. That is, the government manages only rice purchase but the management does not include how to properly operate the production process.

With the policy mis implementation commercial rice farmer are faced with high transaction cost. The commercial rice farming is an activity involving an exchange of assets in the market that lead participants in marketing system to face with competition. In order to gain advantages from such competitive marketing system, inevitably, participants would conceal their information and, in the same time, cannot recognize information widely. This urgent problem of transaction cost must be solved right away, especially the main problem of shortage of methodology of evaluation of transaction cost of peasant economy. These should be seen as the important problems in contemporary situations.

The mission of this research article is to show the measure of transaction cost indicator and evaluation methods of transaction cost in production cycle including suggestion of approach to reduce transaction cost of peasant economy.

\section{Methodology}

The methodology is done by using primary data that classifies the indicators of the nature of transaction cost, proportion of transaction cost and rate of increase of transaction costs in the production units. The data itself is obtained from in-depth interviews in September- December 2010, with employment of sociological research methods. It is indicative that there are two cycles of rice production: the first cycle is from January through April and the second cycle is from June through September. During both cycles of rice production, peasants are faced with natural disasters, that is, excessive rainfall in the first cycle and water shortages in the latter.

Rice prices differently determined by the market conditions of sale; purchase price of the mills participating government's project is higher than the purchase price of the disparticipating mills averagely 1,200 baht per a 
single ton.

The research analysis system (the study of transaction cost of peasant economy producing rice to market and the study of formation condition of transaction cost of peasant economy in relationship marketing system)

The samples used in Research are 3,307 families of commercial rice peasants in Ranote District, Songkhla Province. 100 representatives of those samples are divided into 3 groups: the first group is peasants owning their land with one time farming per one year, the second is peasants owning their land with two times farming per one year and the last group is famers hiring land with two times farming per one year.

All samples are on the condition as peasants who sell rice to mills participating government's projects and peasants who sell rice to disparticipating mills. Both types of mills are located inside and outside area of Ranote District, Songkhla Province. The proportion of interview respondents are male farmer $45 \%$ and $55 \%$ are female.

\section{Literature review}

Transaction cost is cost relative to the use market mechanism. Transaction cost can be categorized in to costs in collecting and interpreting data, cost in negotiation and decision, cost in controlling, cost of contractual obligation. According to Coase, transaction cost affects each cost on economic activities brought by contractual process. In other words, this cost affects the coordination and collaboration of the host economy in a market economy. It is defined by Coase as transaction costs of collaboration between buyers and sellers including birth of market (Coase R.H: 1992, 29) Jones and Hill define transaction cost as cost in monitoring the agreement, which lead into the agreement (Jones G.R., Hill C.W: 1982, 160). Transaction costs arising from cost in the form of clear and unclear the clear cost is in the forms of charges and middlemen's services while the unclear one is from information search and use. M. Aleksejev suggests that transaction cost is trade agreements which leads to costs in transaction involving cost of searching distributor and purchaser, behavior of the negotiations about the topic in the agreement and payment of service instruction and others (Aleksejev M: 1997, 127) Chueng (Chueng S: 1978, 158)sees that participation in the exchange of two or more people causing high transaction costs relative to more cost, apart from cost of production. Menar (Menar K: 1996,29) perceives transaction cost as cost from exchange system or having accuracy in the market economy which is value used in the market to allocate resources and transfer ownership rights. Transaction cost is also viewed as emergency cost, due to the fact that it is caused by exchange.

Researchers have brought this idea to expand in line with the conventions of the peasant economy and market management regulations controlled by the state. Hence, transaction cost can be categorized as transaction cost of information search, transaction cost of entering negotiations, the transaction cost of opportunism, the transaction cost of measurement, the transaction cost of extra asset, the transaction cost of logistics, the transaction cost caused by the government's rice price insurance, the transaction cost of prediction and the transaction cost resulting from the distribution lower than market prices.

The goal of research article is to evaluate transaction cost of commercial rice peasants, as an innovative research indicating the measure of transaction cost merged in rice production cycle, exploring last revenue unit calculated from transaction cost's proportion and showing the method of transaction cost measurement.

\section{Results and discussion}

\subsection{Transaction cost components of Peasant economy in Southern Thailand}

4.1.1 Cost of searching information $\left(\mathrm{C}_{\mathrm{i}}\right)$ on exchanging-rice peasants can be concluded that there are two forms of searching information on rice production: searching information with telephone usage that requires no travel and searching information that requires travel.

The cost of searching information is classified into 3 ranges.

4.1.1.1 Searching information in pre-production range results that among the peasants who search information about weed suppression and insecticide, $28 \%$ of them choose telephone while $72 \%$ choose travel. The percentage of travelling peasants can be further divided as $95.8 \%$ of them have cost and $4 \%$ of them have no cost. For the number of peasants' searching information about rice seed, it results that $39 \%$ of them choose telephone while $61 \%$ choose travel. The percentage of travelling peasants can be further divided as $98.3 \%$ of them have cost and $1.7 \%$ of them have no cost. For the number of peasants' searching information about tractor for first time plowing, it results that $42 \%$ of them prefer telephone while $58 \%$ prefer travel. The percentage of travelling peasants can be further divided as $70.7 \%$ of them have cost and $23.9 \%$ of them have no cost. For the number of peasants' searching rice broadcast workers, it is found that $34 \%$ choose telephone while $66 \%$ choose travel. The percentage of travelling peasants can be further divided as $81.8 \%$ of them have cost and $18.2 \%$ of them have no cost

4.1.1.2 Searching information in production process range results that among the peasants who search information about fertilizer for rice treatment, $49 \%$ of them prefer telephone while $51 \%$ of them prefer travel. The percentage of travelling peasants can be further divided as $96 \%$ of them have cost and $4 \%$ of them have no cost. For peasants' searching information about weeds and pests control workers, it results that $47 \%$ choose telephone while $53 \%$ choose travel. The percentage of travelling peasants can be further divided as $71.7 \%$ of 
them have cost and $28.3 \%$ of them have no cost.

4.1.1.3 Searching information in process of harvest-distribution range, it results that among the number of the peasants who search information about harvesting machine, $54 \%$ of them prefer telephone while $46 \%$ of them prefer travel. The percentage of travelling peasants can be further divided as $87 \%$ of them have cost and $13 \%$ of them have no cost. For peasants' searching information about market with purpose of rice distribution, it results that $26 \%$ of them prefer telephone and $74 \%$ of them prefer travel. The percentage of travelling peasants can be further divided as $82.4 \%$ of them have cost and $17.6 \%$ of them have no cost. In addition, $81 \%$ of all peasants prefer having rice distribution to the mills participating government's project while $14 \%$ of them prefer having rice distribution to local mills and $5 \%$ prefer having rice distribution to mills located outside Ranote District.

Equation in transaction cost of information search done by commercial rice peasants in the study area is

in which

$$
\mathrm{C}_{\mathrm{i}}=\mathrm{P}_{\mathrm{t}} \mathrm{N}_{\mathrm{t}}+\mathrm{P}_{\mathrm{s}} \mathrm{N}_{\mathrm{s}}
$$

$\mathrm{C}_{\mathrm{i}}$ is transaction cost of information search of rice production cycle unit: production cycle

$P_{t}$ is average cost of telephone contact

unit: baht

$\mathrm{N}_{t}$ is number of telephone contact

unit: time

$\mathrm{P}_{\mathrm{s}}$ is average cost of contact with their own

unit: baht

$\mathrm{N}_{\mathrm{s}}$ is number of contact with their own

unit: time

From the table 1 mentioned above, it is indicative that $16 \%$ of peasants searching information with telephone have average cost $129 \mathrm{baht} /$ production cycle whereas peasants searching information with telephone and travel have average cost 196 baht/production cycle, higher than the first group $51.94 \%$. Lastly, peasants searching information with all travels have average cost 326 baht/production cycle, higher than the first and the second group about 2.5 and 1.6 times respectively.

The result shows that each farmer would have different method of information approach as well as different costs. This is not compatible to the economical notion of Neoclassical school that in market system everyone can access the data sources.

4.1.2 Cost of entering negotiations $\left(\mathrm{C}_{\mathrm{n}}\right)$ of commercial rice peasants can be summarized as 2 forms of peasants' negotiations: telephones and travel, and 3 forms of negotiations with harvesting machine: telephones, travel and negotiation with no requirement of travel.

4.1.2.1 Negotiation with tractor for first time plowing results that $70 \%$ of all peasants do with telephone while $30 \%$ do with travel. The percentage of travelling peasants can be further divided as $51.9 \%$ of them have cost and $48.1 \%$ of them have no cost. In addition, $51.9 \%$ of peasants with no cost live nearby tractor's owner but $48.1 \%$ negotiate through neighbors.

4.1.2.2 Negotiation with rice broadcast works results that $22 \%$ of all peasants do with telephone while $78 \%$ do with travel. The percentage of travelling peasants can be further divided as $77.8 \%$ of them have cost and $28.2 \%$ of them have no cost. In addition, $68.2 \%$ of peasants with no cost negotiate through neighboring network while $31.8 \%$ live nearby workers (negotiate with workers themselves).

4.1.2.3 Negotiation with weeds and pests control workers results that $24 \%$ of all peasants do with telephone while $76 \%$ do with travel. The percentage of travelling peasants can be further divided as $61.8 \%$ of them have cost and $38.2 \%$ of them have no cost. In addition, $51.7 \% \%$ of peasants with no cost negotiate through neighboring network while $48.3 \%$ live nearby workers (negotiate with workers themselves).

4.1.2.4 Negotiation with harvesting machine in order to gather products results that $14 \%$ of all peasants do with telephone while $52 \%$ do with travel. The percentage of travelling peasants can be further divided as $73 \%$ of them have cost and $27 \%$ of them have no cost. As the negotiation is done through neighboring network, $34 \%$ have no travel (the machines are brought at home)

4.1.2.5 Negotiation in hiring farm land is occurred among peasants who do not work in their own farm (hiring farm) and can be calculated as $40 \%$ of all peasants. Among peasants hiring farm land, $57.5 \%$ prefer to hire the farm from their own relatives while $42.5 \%$ prefer to hire from acquaintances. $26 \%$ of those peasants are certain that they will be able to continue hiring farm land next year while $74 \%$ are not certain. This is because $30.8 \%$ of uncertain peasants think that the landlords would work in their own farm and $43.2 \%$ think that the landlords would keep the farm land for their own children.

Equation of the transaction costs to enter the negotiation of commercial rice peasants in the study area is

$$
\mathrm{C}_{\mathrm{n}}=\mathrm{T}_{\mathrm{n}}+\mathrm{P}_{\mathrm{n}}+\mathrm{M}_{\mathrm{n}}+\mathrm{H}_{\mathrm{n}}+\mathrm{R}_{\mathrm{n}}
$$

in which $\quad \mathrm{C}_{\mathrm{n}}$ is Cost of entering negotiation unit: production cycle

$T_{n} \quad$ is Costs of negotiation with tractors for first time plowing

$\mathrm{P}_{\mathrm{n}} \quad$ is $\quad$ Cost of negotiations with broadcast workers 


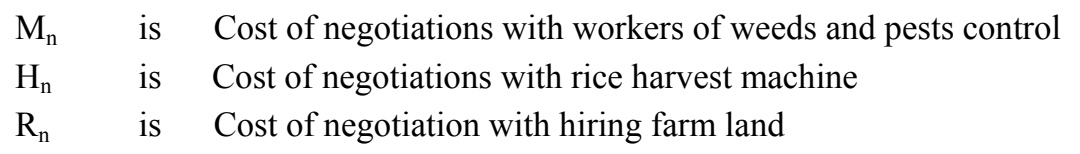

According to the table above, it is suggestive that the percentage of peasants, having their own farm, with no cost and having cost below 50 baht are $3 \%$ and $5 \%$ respectively, whereas the percentage of peasants with cost 50-100 baht are $27 \%$ and $18 \%$, working in their own farm and land lease.

The study result reveals that every cost need negotiation done in various forms and the need leads distinctive transaction cost.

4.1.3 Cost of opportunism is found that it is occurred during the process of product harvest (machines hired on the harvest). That is, the machines cannot completely harvest the product and make farmer lose their product in harvesting process. $22 \%$ of all peasants explain that because the machines are old, $24 \%$ complain the machine's proficient, pointing that the machines rapidly work in order to work for other peasants, $18 \%$ state that the machine work rapidly to finish harvest in time and $6 \%$ say that the machine carry too much rice that make some of those rice fall down while working.

The study results that average of damage caused by opportunism of the machine at about $3.6 \mathrm{~kg} /$ rai $(1,600$ square meters). Equation in the calculation of damage caused by opportunism of the machine is $\mathrm{C}_{\mathrm{o}}=\mathrm{P}_{\mathrm{a}} \mathrm{W}_{\mathrm{a}}$

In which

$$
\begin{aligned}
& \mathrm{C}_{o} \quad \text { is transaction cost caused by opportunism of the machine unit: baht/rai } \\
& \mathrm{P}_{\mathrm{a}} \quad \text { is average price of paddyunit: Baht/ Kg } \\
& \mathrm{W}_{\mathrm{a}} \quad \text { is the average loss of weight unit: } \mathrm{Kg} / \text { rai }
\end{aligned}
$$

According to the table number 3, peasants selling rice to mill participating government's project, as $39 \%$ of all peasants, have higher value of damage than peasants selling rice to disparticipating mills( both inside and outside area) because the rice price of participating mills is higher than another one $17.2 \%$ per cost of 1 rai. The value of damage is relative to number of peasants' plots.

That is, the more rice plot means the higher cost or transaction cost caused by harvesting machine's opportunism (1 rice plot $=1$ rai)

4.1.4 Cost of measurement is found, by the study, that consist of 2 forms

4.1.4.1 The cost of measuring in use of fertilizer $\left(\mathrm{C}_{\mathrm{me}}\right)$ It is found that the standardization of peasants' use of fertilizer is $50 \mathrm{Kg} / 1$ rai of rice plot, and $58 \%$ of peasants are able to sow the fertilizer upon such standardized amount. In contrast, $42 \%$ of them cannot sow the fertilizer upon the standardized amount and must add the fertilizer into rice plot. $19 \%$ of peasants believe that adding fertilizer can accelerate productivity, $31 \%$ believe that distances between rice planted in plot are not appropriate, $24 \%$ believe that soil of plot is not fertile, $21.4 \%$ believe that soil of plot has depth and causes much flooding in plots and $26.2 \%$ believe that adding fertilizer is resulted from increasing seed.

According to the study result, average deviation caused by the use of fertilizer is $2.6 \mathrm{Kg} / \mathrm{rai}$, which can be used in cost of average deviation of fertilizer use in equation $\mathrm{C}_{\mathrm{me}}=\mathrm{P}_{\mathrm{a}} \mathrm{N}_{\mathrm{a}}$

In which

$$
\begin{array}{lll}
\mathrm{C}_{\mathrm{me}} & \text { is transaction cost caused by average deviation of fertilizer use unit: baht } / \mathrm{rai} \\
\mathrm{P}_{\mathrm{a}} & \text { is average price of fertilizer } & \text { unit: baht } / \mathrm{Kg} \\
\mathrm{N}_{\mathrm{a}} & \text { is deviation of average weight } & \text { unit: } \mathrm{Kg} / \mathrm{rai}
\end{array}
$$

4.1.4.2 The capital of seed use measurement $(\mathrm{Cs})$. It is found that farmer's standardization of seed $\$$ use is 20 $\mathrm{Kg} / \mathrm{a}$ rai. Only $6 \%$ peasants who having ability to sow seeds in accordance with the standardization, and the rest $94 \%$ must increase the seeds in rice plots to compensate low productivity caused by pest damage. The average deviation caused by the use of seed is found at $3.8 \mathrm{Kg}$ and can'be used to calculate the cost of average deviation of the use of seeds according to equation $\mathrm{C}_{\mathrm{me}}=\mathrm{P}_{\mathrm{a}} \mathrm{N}_{\mathrm{a}}$

$\begin{array}{lll}\text { In which } & \mathrm{C}_{\mathrm{me}} & \text { is Transaction cost caused by deviation of fertilizer use unit baht: rai } \\ & \mathrm{P}_{\mathrm{a}} & \text { is Average price of fertilizerunit: baht } / \mathrm{Kg} \\ \mathrm{N}_{\mathrm{a}} & \text { is Deviation of average weight unit: } \mathrm{Kg}\end{array}$

From the calculation, the price of seed found in found in local area is fixed as $20 \mathrm{bath} / \mathrm{Kg}$ and the use of seed with deviation average $3.8 \mathrm{Kg} / \mathrm{rai}$, representing a cost $76 \mathrm{bath} / \mathrm{rai}$

4.1.5 The cost of assets' uniqueness is caused by the certain characteristic of rice as it principally relies on natural system. The cost of assets' uniqueness, according to the study, can be categorized into 2 groups:

4.1.5.1 The cost of peasants' use of water pump $(\mathrm{Cw})$. The average cost of peasants' use of water pump is 25 baht per a single time $87 \%$ of all peasants agree that the water pump is necessary because helps them to easily 
control water level in rice plots, and $11 \%$ of peasants point that the certain characteristic of area-locating nearby the lake-requires the accelerate plot drainage in every raining time. Besides, peasant can pump water up instantly when need of water, and $2 \%$ explain that use of water pump can provide a rapid production within short production. The calculation of cost of water pump can be done to equation $\mathrm{C}_{\mathrm{w}}=\mathrm{P}_{\mathrm{a}} \mathrm{N}_{\mathrm{a}}$

In which

$$
\begin{array}{ccl}
\mathrm{C}_{\mathrm{w}} & \text { is transaction cost of water pump use } & \text { unit: baht/rai } \\
\mathrm{P}_{\mathrm{a}} & \text { is average cost of water pump } & \text { unit: baht/time } \\
\mathrm{N}_{\mathrm{a}} & \text { is average number of water pump use } & \text { unit: time/ rai }
\end{array}
$$

The research found that all peasants' water pumps average 3 times/rai and the calculating result shows the cost of water pump use in a production cycle average 75 bath/rai

4.1.5.2 Cost of drought risk $\left(\mathrm{C}_{\mathrm{d}}\right)$. Peasants' farming 2 times/ year (second production cycle) lacks of water for rice production. The study found that the peasants farming thoroughly in second production cycle (June-September) lack their own products. To clarify, $57.1 \%$ lose entire product; $30 \%$ lose harf of product in second production cycle, equivalent to the loss of 3 sacks of rice for a farm unit (rai) and $12.9 \%$ lose product average $67 \%$ of the amount of product in second production cycle, equivalent to 4 sacks of rice.

The damage caused by drought can be used in transaction cost calculation with equation $\mathrm{C}_{\mathrm{d}}=\mathrm{P}_{\mathrm{a}} \mathrm{N}_{\mathrm{a}}$.

In which $C_{d}$ is transaction cost caused by drought

unit: baht/rai

$\mathrm{P}_{\mathrm{a}} \quad$ is Average cost of a kilogram of rice

unit: baht

$\mathrm{N}_{\mathrm{a}} \quad$ is Average weight of rice in a farm unit (rai)

unit: $\mathrm{Kg} / \mathrm{rai}$

According to the table number 5, the arrival of drought (shortage of water for rice production) makes peasants lose revenue of their product distribution, since the difference in revenue depends on rice market. Peasants selling their product to mills participating government's project lose average revenue as 4,866 baht/ 1 rai while peasants selling their product to disparticipating mills lose average revenue as 4,140 baht/ rai, suggesting that the difference of price in market varies the value of loses.

4.1.6 Logistic cost $\left(\mathrm{C}_{1}\right)$ is expenses which peasants lose in the process of shipping products to the mills ( rice market), occurred when peasants, who sell rice to participating mills, pay for transportation of rice to the mill at a price per ton 300 Baht or about $180 \mathrm{baht} / 1$ rai product.

4.1.7 Cost of government's rice price guarantee $\left(C_{p}\right)$, peasants participate in government's guarantee at 10,000 baht per a ton of product or 10 baht per kilogram under condition that weight that the government compensate to peasants' product is 545 per a rai, but the average product of regional peasants is 600 kilogram per 1 rai of rice farming. This means peasants will not be able to receive government's guarantee to their products 55 Kilogram per 1 rai of rice farming, equivalent to cost 500 baht in a unit farming.

4.1.8 Cost Estimates $\left(\mathrm{C}_{\mathrm{e}}\right)$ is value of loses caused when peasants' product distribution lower than estimate. The study found that $80 \%$ of all peasants want to sell their rice to mills participating government's project. Because of high price distribution, $16 \%$ of peasants would like to sell the rice to regional mills; $37.5 \%$ decide to sell their rice to regional mill because of having no cost of rice transportation; $62.5 \%$ are from the close relationship between peasants and mills, and $4 \%$ of peasants' decision to have rice distribution to mills outside from the region are from the reason that the external mills would pay sooner than internal mills.

From the estimates of peasants deciding to trade their rice to participating mills, there are $52.5 \%$ of peasants whose trades are lower than estimates; this is because $35.7 \%$ of peasants harvest before the mills begin to purchase but $64.3 \%$ complete their harvest after mills' purchase (participating mills stop purchasing earlier). Having no distribution to participating mills causes peasants' loss of revenue about $720 \mathrm{baht} / 1 \mathrm{rai}$

4.1.9 Cost of trading product below market price $\left(\mathrm{C}_{\mathrm{m}}\right) .38 \%$ of peasants sell their rice to mills participating government's project and $62 \%$ sell their rice to mills disparticipating goverenment's project (regional and outsiding mills) Peasants who sell rice to disparticipating mills are faced with rice price lower than distribution to participating mills 1,200 baht per ton, equivalent to value of loses $720 \mathrm{baht} /$ product in 1 rai

The research results that the transaction cost of peasants' rice production cycle in study area can be summarized as the difference of rice market with equation

$$
\mathrm{T}_{\mathbf{z c}}=\mathbf{C}_{\mathbf{i}}+\mathbf{C}_{\mathbf{n}}+\mathbf{C}_{\mathbf{o}}+\mathbf{C}_{\mathrm{me}}+\mathbf{C}_{\mathrm{s}}+\mathbf{C}_{\mathrm{w}}+\mathbf{C}_{\mathrm{l}}+\mathbf{C}_{\mathbf{p}}+\mathbf{C}_{\mathrm{e}}+\mathbf{C}_{\mathrm{m}}
$$

From the table above, rice distribution to participating mills provide expense as transaction cost 1,672 baht/ 1 rai, equivalent to $34.4 \%$ of product price of participating mills, whereas rice distribution to disparticipating mills provide expense as transaction cost 1,488 baht/ 1 rai, equivalent to $35.9 \%$ of product price of disparticipating mills

\subsection{Analysis of marginal profit from rice production in a farming unit}

Analysis of marginal profit from Rice Production in a Farming Unit of the study area can be calculated from equation: marginal revenue $\left(\mathrm{I}_{\mathrm{lu}}\right)=$ total revenue $\left(\mathrm{T}_{\mathrm{r}}\right)$-production $\operatorname{cost}\left(\mathrm{P}_{\mathrm{c}}\right)-\operatorname{transaction} \operatorname{cost}\left(\mathrm{T}_{\mathrm{zc}}\right)$ 
The calculation shows that difference of mills or rice markets chosen by peasants provide only $1.5 \%$ of transaction cost distinction, equivalent to the expense of difference in estimated transaction cost, which is 184 baht.

Research found that peasants working in the land of their own have average production cost at 2,050 baht/rai ,equivalent to $42.31 \%$ of average price in participating mills and $49.52 \%$ of average price in disparticipating mills.

Peasant working in land lease have average production cost at 2,550 baht/rai, equivalent to $52.04 \%$ of average price in participating mills and $61.59 \%$ of average price in disparticipating mills.

Calculating marginal revenue of peasants working in the land of their own, it reveals the marginal revenue of rice distribution to participating mills is $1,444 \mathrm{baht} /$ rai while the marginal revenue of rice distribution to disparticipating mills (regional and outsiding) is 602 baht/rai.

For peasants working in the land lease, it reveals the marginal revenue of rice distribution to participating mills is $644 \mathrm{baht} /$ rai while the marginal revenue of rice distribution to disparticipating mills (regional and outsiding) is $102 \mathrm{baht} / \mathrm{rai}$.

The research found that farming in the first production cycle does not cause problems of risk of assets resulting from drought. Having rice distribution to mills participating government's project is appropriate for decision-making of position in circulation and the return of cost to enter the production cycle. This is because the percentage of increase in transaction costs in different markets will be lower than the percentage of increase in rice prices caused by the difference in sales which are $12.4 \%$ and $17.54 \%$ respectively.

\subsection{The coefficient of transaction cost efficiency $\left(K_{e t}\right)$}

The coefficient of transaction cost efficiency $\left(\mathrm{K}_{\mathrm{et}}\right)=$ profit in each production cycle/ total expenditure on transaction costs. From the calculation of the coefficient of transaction cost efficiency to evaluate the proficiency of peasant economy chain, it results that peasants trading rice to participating mills have $\mathrm{K}_{\mathrm{et}}$ as 1.53 -i.e. in proportion of profit 1.53 baht there is expense as transaction cost 1 baht. Meanwhile, peasants trading rice to disparticipating mills have $\mathrm{K}_{\mathrm{et}}$ as 1.24-.e. in proportion of profit 1.24 baht there is expense as transaction cost 1 baht. Transaction cost that occurred guarantees that product can be sold through the process successfully. Transition of indicator of average profit from peasant economy distribution can be calculated from equation $\mathrm{I}=\mathrm{P}_{\mathrm{a}} / \mathrm{V}+\mathrm{P}_{\mathrm{p}} / \mathrm{V}$

In which I is transition of profit indicator from peasant economy distribution

$\mathrm{P}_{\mathrm{a}} \quad$ is profit remaining after paying transaction costs

$\mathrm{P}_{\mathrm{p}} \quad$ is part of the profits to pay transaction costs

$\mathrm{V} \quad$ is value of sales (baht/rai)

The result of calculation of transition of profit indicator from peasant economy distribution is 0.62 , suggesting that increasing transaction cost in peasant economy with profit can lead to increasing and decreasing volume of distribution. This means implementing the mechanism of the split transaction costs effects control and changes in the size of the volume of distribution, as well as influencing the performance of sales activity. If the growth rate of transaction costs by living with earnings is faster than the growth rate of distribution volume, the investment in peasant economy will be even irrational. This problem must be solved instantly by focusing on innovation (infrastructure and strategic access to the market) in peasant economy activity.

The explanation of proficiency of peasant economy activity can be done via equation: never losing indicator $=$ transaction cost of fixed cost* value of peasant economy distribution, in which the value of peasant economy distribution is the difference between value of peasant economy distribution and cost.

The computation of proficiency in peasant economy activity comes to the idea that the proficiency depending on price of product distribution will be occurred when transaction costs between different types of the rice market (participaing and disparticipating mills) is not higher than $32 \%$. But if the difference is higher than $32 \%$, the proficiency will rely on transaction cost.

\subsection{Ways to reduce transaction cost of peasant economy}

Research has shown that the highest transaction costs are fixed costs, which occurs $1,450 \mathrm{baht} / 1 \mathrm{rai}$, equivalent to $86.72 \%$ of mills participating in government's project and $1,270 \mathrm{baht} / 1$ rai, equivalent to $85.35 \%$ of mills disparticipating government's project. The total fixed transaction costs caused by handling products to the market process, rice price guarantee by government and stop purchasing of mills participating in government's project (only a few markets). Cause arising from the methodology of policy -making that is not affiliated with the peasant since the beginning of the reproduction process and a lack of peasants' accurate estimate in rice production. And if the government has the organizing of purchasing system or mills in product storage including accurate estimate of production level, transaction cost of peasant economy will be decreased to $86 \%$ of occurred transaction cost or 1,360 baht/ a rai or 5,789,520 baht in sample of peasant.

However, government, as controller and intervener the policy in rice market, should truly consider relationship 
model of partnership in equity markets. Transaction cost, variously occurred in rice market, should be operated with the basis of a partnership to work in the long term, including there should be guarantee of infrastructure in Peasant economy production. Hence, risk and opportunism effecting transaction costs will be decreased and the opportunity to build equity in the distribution of assets as a source of wealth of the nation.

\section{Conclusion}

From the research, it is obvious that for commercial rice planter, transaction cost is an significant indicator used in calculation of marginal revenue, shown in number as 1,580 baht per a farming unit (rai). In addition, the study found that among three peasants' categories transaction costs are not mostly alike. The difference can be found in range of production cycle; the second production cycle has risk of transaction cost for shortage of water, which is an infrastructural problem in production must be controlled by government. The different amount of transaction cost is resulted in types of cost- i.e. transaction cost is problematic cost which peasant cannot handle, avoid or even decrease it. Government's making, advocating and implementing of policy inevitably involve peasants in economic operation. Hence, the value of peasant economy when entering to market is in distribution price, transportation and market selection for distribution (regional and outsiding mills) which are uncontrollable processes.

Although government attempt to assist and enhance peasant's well-being, it cannot solve the problem of appropriateness in profit. This is because government's policy implementation on rice market is principal cause of transaction cost of peasant economy plus with lacking of collaboration as long tern partner. The previous performance of government is so called hypocrite because government focus on short term political polity rather than long term collaboration to create the proper environment and sustainable ways to bright future market.

\section{References}

Aleksejev M. M. (1997). Planirovanije deyatelnosti firmy: Uchebno-metodicheskoje posobije. M.: Finansy i statistika.

Chueng S.N.S. (1978). The myth of social costs. L.

Coase R.H. (1992). The Comment-Contract economics. Blackwell Publishers, p.173.

Jones G.R., \& Hill C.W.L. (1982). Transaction costs analysis of strategy structure choice. Strategic management journal, vol.9, pp.159-172.

Menar K. (1996). Economika organizaci:Per s fr.; Pod red. Hudokormova A.G.-M.: INFRA-M. P.37

Table 1. Cost of searching production information, depending on variety information access

\begin{tabular}{|l|l|l|}
\hline Number of farmer: person & Model for production information & Average cost: baht/production cycle \\
\hline 16 & All telephones & 129 \\
\hline 53 & Telephone and travel & 196 \\
\hline 31 & All travels & 326 \\
\hline
\end{tabular}

Source: Field Work 2010

Table 2. Cost in Negotiation

\begin{tabular}{|c|c|c|c|c|c|}
\hline \multirow{3}{*}{ Farmer (person) } & \multicolumn{4}{|c|}{ Cost in process } & \multirow{3}{*}{$\begin{array}{c}\text { Total } \\
\text { number } \\
\text { (person) }\end{array}$} \\
\hline & \multirow{2}{*}{ No cost } & \multicolumn{3}{|c|}{ Having cost } & \\
\hline & & Below 50 baht & $50-100$ baht & More than $100 \mathrm{baht}$ & \\
\hline The land of their own & 3 & 26 & 27 & 4 & 60 \\
\hline Land lease & - & - & 18 & 22 & 40 \\
\hline
\end{tabular}

Source: Field Work 2010

Table 3. The amount of money the peasants lose with harvesting machine's opportunism

\begin{tabular}{|c|c|c|c|c|}
\hline $\begin{array}{c}\text { Number } \\
\text { of farmer }\end{array}$ & Rice market & Riceprice/ Kg & $\begin{array}{c}\text { The amount of lost rice } \\
\text { averagely Kg/rai }\end{array}$ & $\begin{array}{c}\text { The amount of } \\
\text { lost money }\end{array}$ \\
\hline 39 & Participating mills & 8.11 & \multirow{2}{*}{3.6} & 29.12 \\
\hline 61 & Disparticipating mills & 6.9 & & 24.84 \\
\hline
\end{tabular}

Source: Field Work 2010 
Table 4. Value of losses in 1 rai (a farm unit) calculated with drought risk

\begin{tabular}{|l|l|l|l|l|}
\hline Rice market & Average price $/ 1 \mathrm{Kg}$ & $\begin{array}{l}\text { Weight of rice } \\
/ 1 \text { sack }\end{array}$ & $\begin{array}{l}\text { Amount of } \\
\text { money/sack }\end{array}$ & $\begin{array}{l}\text { Amount of } \\
\text { money/rai }\end{array}$ \\
\hline Participating mills & $8.11 \mathrm{baht}$ & \multirow{2}{*}{$100 \mathrm{Kg} / \mathrm{sack}$} & $811 \mathrm{baht}$ & $4,866 \mathrm{baht}$ \\
\cline { 1 - 1 } $\begin{array}{l}\text { Disparticipating mills } \\
\text { (Inside and outside of area) }\end{array}$ & $6.9 \mathrm{baht}$ & $690 \mathrm{baht}$ & $4,140 \mathrm{baht}$ \\
\hline
\end{tabular}

Source: Field Work 2010

Table 5. The amount of transaction cost occurred in rice production cycle under difference of rice market Distribution unit: baht

\begin{tabular}{|l|l|l|l|l|l|l|l|l|l|l|l|}
\hline Trading market & \multicolumn{7}{|c|}{ Average transaction cost/ a farming unit (1 rai) } & \multirow{2}{*}{ Total } \\
\hline & $\mathrm{C}_{\mathrm{i}}$ & $\mathrm{C}_{\mathrm{n}}$ & $\mathrm{C}_{\mathrm{o}}$ & $\mathrm{C}_{\mathrm{me}}$ & $\mathrm{C}_{\mathrm{s}}$ & $\mathrm{C}_{\mathrm{w}}$ & $\mathrm{C}_{1}$ & $\mathrm{C}_{\mathrm{p}}$ & $\mathrm{C}_{\mathrm{e}}$ & $\mathrm{C}_{\mathrm{m}}$ & Tol \\
\hline Participating mills & 5.3 & 1.75 & 29.12 & 34.6 & 76 & 75 & 180 & 550 & 720 & 0 & 1,672 \\
\hline Disparticipating mills & 5.3 & 1.75 & 24.84 & 34.6 & 76 & 75 & 0 & 550 & 0 & 720 & 1,488 \\
\hline
\end{tabular}

Source: Field Work 2010

Table 6. Production cost and transaction cost in a farming unit or rai (baht)

\begin{tabular}{|c|c|c|c|}
\hline Ownership of the land & Production costs & $\begin{array}{c}\text { Transaction costs of } \\
\text { participating mills. }\end{array}$ & $\begin{array}{c}\text { Transaction costs of } \\
\text { disparticipating mills. }\end{array}$ \\
\hline The land of their own & 2,050 & 1,672 & 1,488 \\
\hline Land lease & 2,550 & 1,672 & 1,488 \\
\hline
\end{tabular}

Source: Field Work 2010 